\title{
Vibration Spectrum Analysis for Indicating Damage on Turbine and Steam Generator Amurang Unit 1
}

\author{
Beny Cahyono ${ }^{1}$, Dwi Priyanta ${ }^{2}$, Fakhri Rizqullah Fajar Ramadhan ${ }^{3}$
}

\begin{abstract}
- maintenance on machines is a mandatory asset management activity to maintain asset reliability in order to reduce losses due to failure. $89 \%$ of defects have random failure mode, the proper maintenance method is predictive maintenance. Predictive maintenance object in this research is Steam Generator Amurang Unit 1, which is predictive maintenance is done through condition monitoring in the form of vibration analysis. The conducting vibration analysis on Amurang Unit 1 Steam Generator is because vibration analysis is very effective on rotating objects. Vibration analysis is predicting the damage based on the vibration spectrum, where the vibration spectrum is the result of separating time-based vibrations and simplifying them into vibrations based on their frequency domain. The transformation of time-domain-wave into frequency-domain-wave is using the application of FFT, namely AMS Machinery. The measurement of vibration value is done on turbine bearings and steam generator of Unit 1 Amurang using Turbine Supervisory Instrument and CSI 2600 instrument. The result of this research indicates that vibration spectrum from Unit 1 Amurang Power Plant indicating that there is rotating looseness, even though the vibration value does not require the Unit 1 Amurang Power Plant to stop operating (shut down). This rotating looseness, at some point, can produce some indications that similar with the unbalance. In order to avoid more severe vibrations, it is necessary to do inspection on the bearings in the Amurang Unit 1 Power Plant.
\end{abstract}

Keywords - predictive maintenance, turbine and generator, vibration analysis, vibration spectrum

\section{INTRODUCTION ${ }^{1}$}

$\mathrm{M}$

aintenance on the machine is a mandatory activity

in asset management to maintain asset reliability in order to reduce the chance of losses due to machine failure. Therefore, the Power Plant must be properly maintained to keep the Unit in a productive state. Predictive maintenance is a maintenance activity that aims to prevent more severe damage by detecting potential damage [1].

The main focus of predictive maintenance is to look for potential damage before the damage occurs. One of the predictive maintenance used in Amurang power plant is vibration analysis.

In vibration analysis, vibration has particular characteristics that are used to detect the damage of engine components[2]. This vibration is a mixture of various vibrations, thus a precise method is needed to separate the observed component signal with another signal, that is the FFT (Fast Fourier Transform) method[4]. Furthermore, this signal is processed to obtain information on the state of the machine or equipment which is being monitored[2-5].

Data collection of condition monitoring assisted by colleagues from Java-Bali Power Plant Muara Karang. The data obtained by recording the vibration in Amurang

Beny Cahyono, Department of Marine Engineering, Institut Teknologi Sepuluh Nopember, Surabaya 60111, Indonesia, Email : cak_beny@yahoo.com

Dwi Priyanta, Department of Marine Engineering, Institut Teknologi Sepuluh Nopember, Surabaya 60111, Indonesia, Email : priyanta@gmail.com

Fakhri Rizqullah Fajar Ramadhan, Department of Marine Engineering, Institut Teknologi Sepuluh Nopember, Surabaya 60111, Indonesia, Email : fakhri.rizqullah6@gmail.com
Unit 1 using displacement sensor and velocity sensor. The Amurang power plant that located in North Sulawesi commenced operations in 2013, has the following specifications:

- Turbine

Type

Manufacturer

: Steam

Power Output

:Qingdao Jieneng

Turbine Operational Speed

Main Steam Pressure : $25.000 \mathrm{~kW}$

Main Steam Temperature

:3000 RPM

$: 8,83 \mathrm{MPa}$

: $535^{\circ}$ Celcius

- Generator

Manufacturer

Output Frequency

Generator Op. Speed

Rated Voltage

Rated Current

Excitation Current

: Shandong Jinan
$: 50 \mathrm{~Hz}$
$: 3000 \mathrm{RPM}$
$: 10500 \mathrm{~V}$
$: 1718 \mathrm{~A}$
$: 351 \mathrm{~A}$

\section{METHOD}

\section{A. Vibration}

Vibration is an oscillation motion around a starting point. Vibration that generated on a machine can describe the condition of unwanted movements on machine components. The total number of cycles of movement in every second is called "Frequency" and is expressed in "Hertz" (Hz) [6-9]. Vibration is caused by force and responded with the form of oscillation movement. The oscillation movement can be described in the form of displacement, velocity and acceleration [10-11].

Displacement is indicating how large the object vibrates. The displacement is measured by peak to peak, i.e. peak (the highest) to peak (the lowest) or $2 \mathrm{x}$ of amplitudes. Displacement is measured by a sensor that 
commonly known as displacement probes. The units which are used; mils for imperial unit systems or microns for metric unit systems. The displacement sensor has a high effectiveness when measuring vibration at low frequencies, specifically below $10 \mathrm{~Hz}$ [12-14].

Velocity or speed is indicating how fast the object vibrates. The units used are mils / s for imperial unit systems or $\mathrm{mm} / \mathrm{ns}$ for metric unit system. Velocity measures the level of vibration signal to displacement alteration. This is the most common measurement of engine vibration. However, Velocity loses its effectiveness in its measurements at very low frequencies (below $10 \mathrm{~Hz}$ ) and also at higher frequencies (above $1000 \mathrm{~Hz}$ ) [15-16].

Acceleration is an alteration of the velocity of the vibrating object related to the force / disruption that causes vibration $\left(\mathrm{mm} / \mathrm{s}^{2}\right.$ or $\left.\mathrm{inch} / \mathrm{s}^{2}\right)$. The maximum acceleration exists when the changed-direction displacement occurs, i.e. when vibration at the maximum displacement and zero speed. The units that used are inches $/ \mathrm{s}^{2}$ for imperial unit systems or $\mathrm{mm} / \mathrm{s}^{2}$ for metric units or unit $\mathrm{g}$, where $1 \mathrm{~g}$ is $9,807 \mathrm{~m} / \mathrm{s}^{2}$ or $386,4 \mathrm{in} / \mathrm{s} 2$. Acceleration sensors have a high effectiveness when measuring vibrations at high frequencies, i.e. above 100 $\mathrm{Hz}[14]$.

\section{B. Time Domain and Frequency Domain}

Vibration that occurs in machinery is a combination of many vibrations, all the complex vibrations that occur can be disparted into simpler waves [7]. These simpler waves have different amplitudes and frequencies, then from different amplitude and frequency, there formed a set of wave with a frequency domain, this method is called Fourier Transform. When all these simple waves are combined, the complex waves are re-formed [17-19].

Fourier Transform is a method for converting vibration signals from time domain to frequency domain. Fourier Transform is called Fast Fourier Transform because the method was invented by French mathematician Jean Baptise Fourier that made transformation become fast [4]. Time domain analysis provides a physical representation of the original vibration frequency but it is difficult to analyze practically if the vibration signal is complex. To ease the analysis, frequency domain data is used as it provides more detailed information in identifying the damage [2022].

Figure 1.a are two sinusoidal waves. The upper wave has a frequency $4 \mathrm{x}$ larger than the lower wave and amplitude is $1 / 4 x$ the lower wave. The combination of the two waves is illustrated in Figure 1.b with the time domain oscilloscope shown in Figure 1.d. Figure 1.e has the same data as the Figure 1.d which is viewed through the frequency domain where the vertical line is proportional to the magnitude of the amplitude. Figure 1.c is a three-dimensional analogy between time domain and frequency domain. This method (Fourier Transform) is a change of viewpoint in viewing complex waves [20].

To convert complex waves from time domain to frequency domain, it requires mathematical software. The mathematical software that is used to transform the vibration signal from the time domain to the frequency domain is Asset Management System (AMS) Machinery.
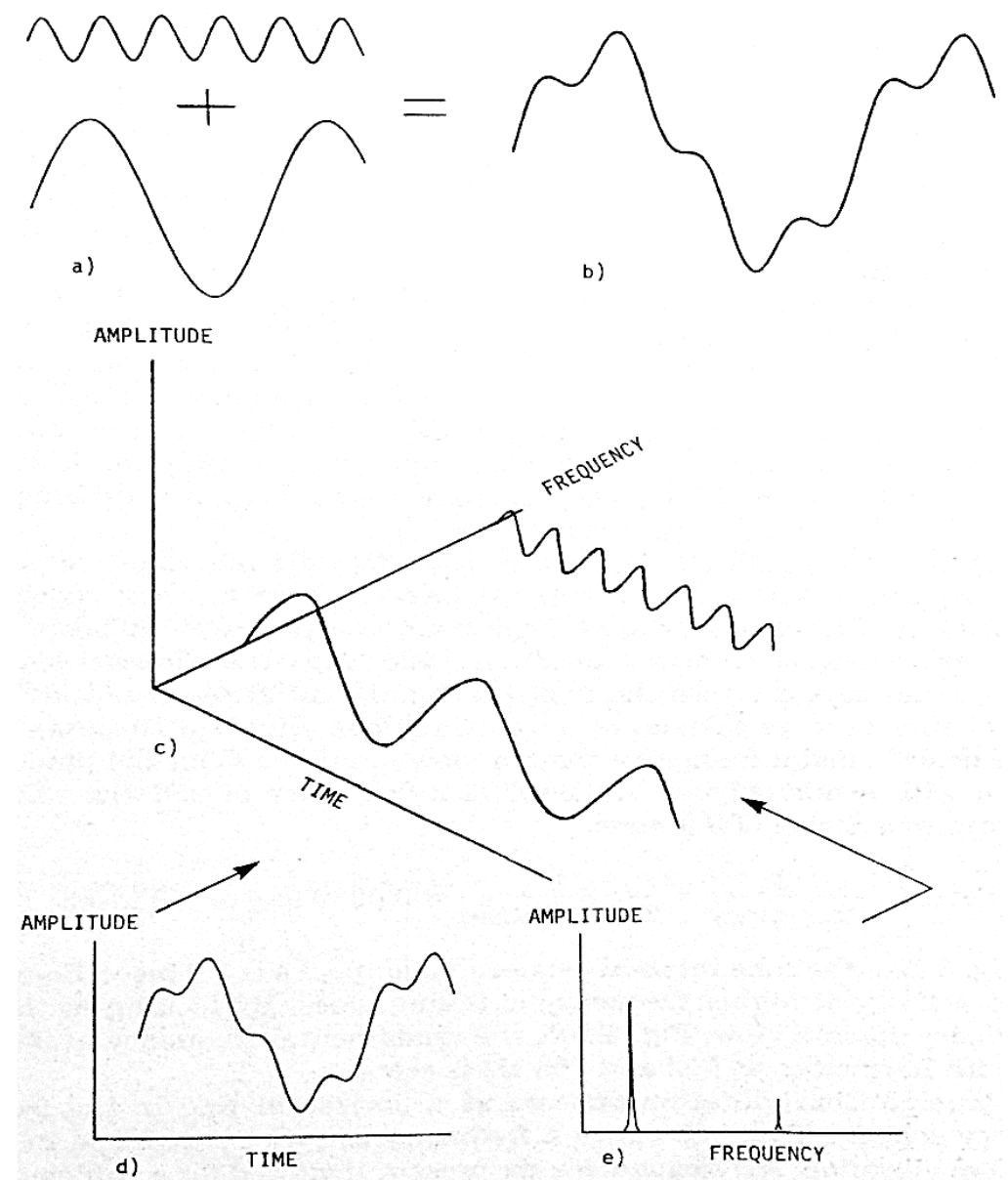

Figure. 1. The differences between time domain and frequency domain wave. 


\section{Failure Indication on Vibration Spectrums}

Vibration spectrum on these research has seven types of indication, there are unbalance, shaft misalignment, journal bearing failure (looseness and oil whril), ball bearing failure, bent shaft, looseness (structural looseness and rotating looseness) and gear deflect [21]. Table 1 shows seven types of indication with nine different spectrums:

TABLE. 1.

FAILURE INDICATION ON VIBRATION SPECTRUMS[6-19]

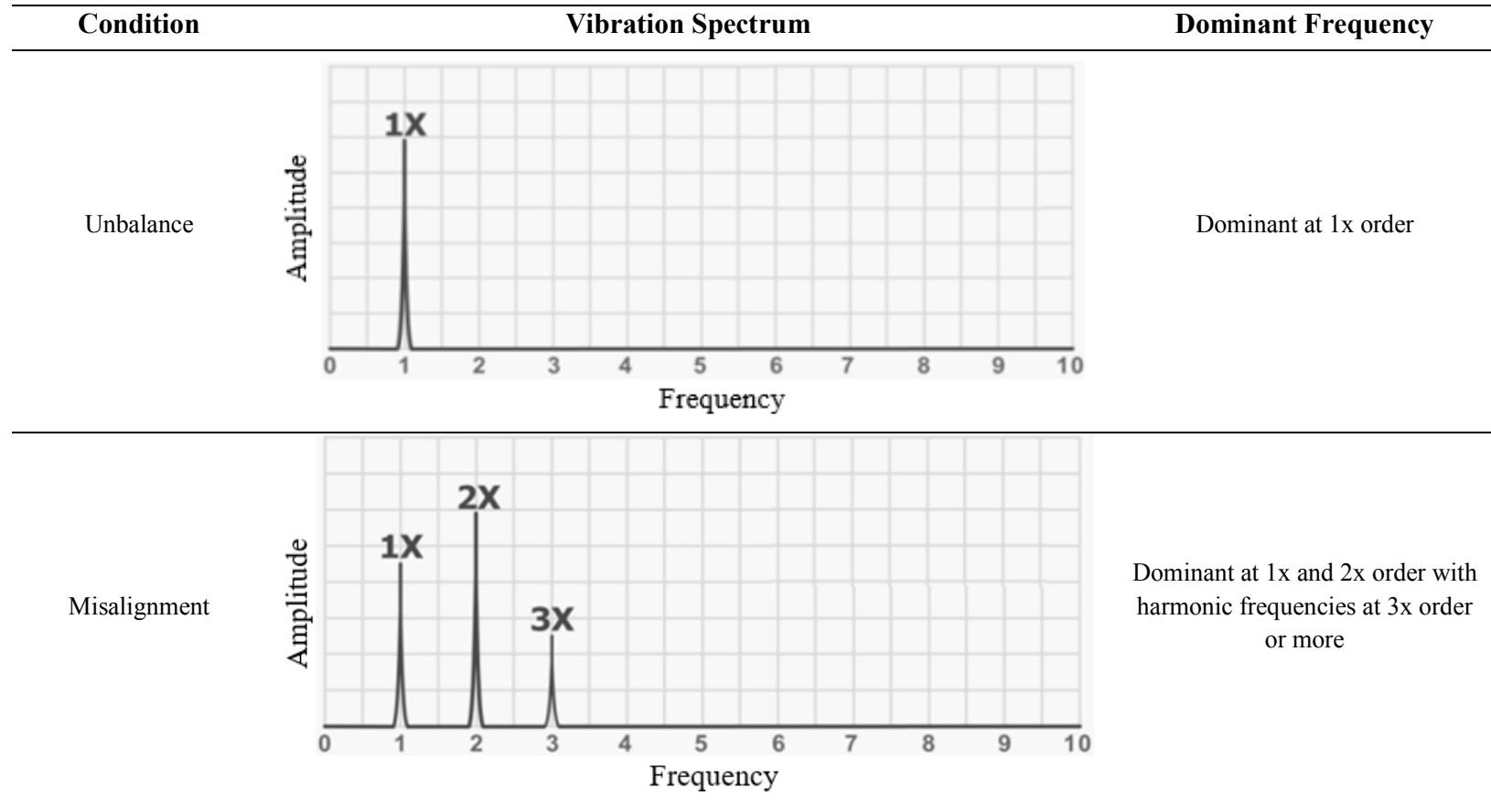

Journal Bearing Looseness

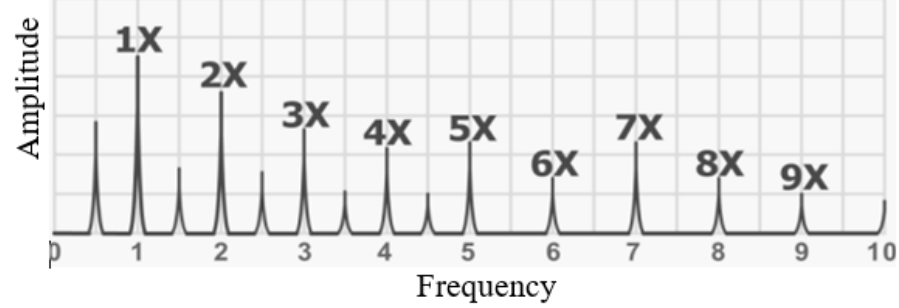

Dominant at $1 \mathrm{x}$ order with harmonic frequencies of half to one multiples order

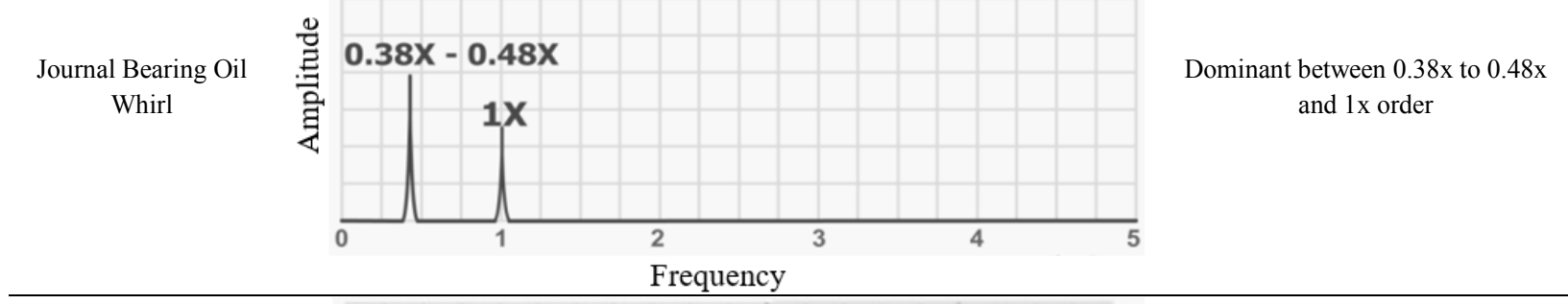

Ball Bearing Failure

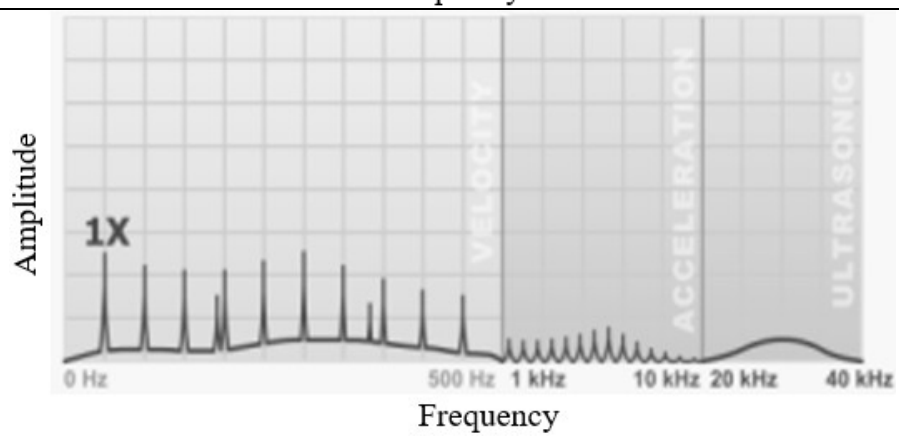

Dominant at $1 \mathrm{x}$ order and very high order. The vibration usually has a frequency of 20-40x order 
TABLE. 1.

(CONT.) FAILURE INDICATION ON VIBRATION SPECTRUMS[6-19]

\begin{tabular}{ll|l|l|l|}
\hline Condition & \multicolumn{9}{c|}{ Vibration Spectrum } & Remark \\
\hline Bent Shaft & & & & \\
\hline
\end{tabular}
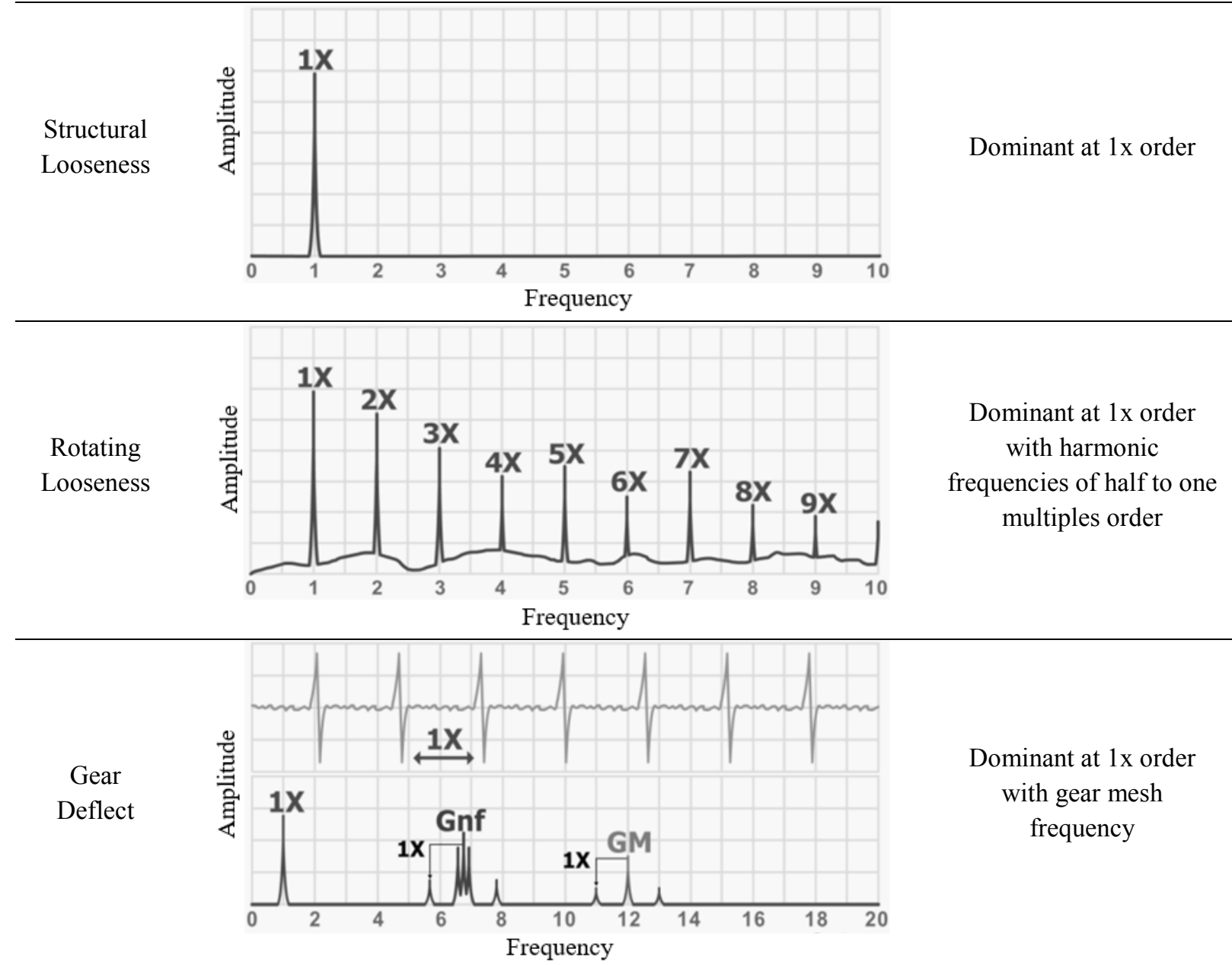
Dominant at $1 \mathrm{x}$ order with gear mesh frequency

\section{International Standards for Vibration Measurement}

ISO 7919 is an international standard of measurement performed on rotating components such as axle, bearing, rotor shaft and others. ISO 7919 is used when measuring using displacement probes. and for Amurang Power Plant is using ISO 7919-3 (Fig. 2) [8].

ISO 7919-3 provides guiandce for applying the evaluation criteria on a shaft vibration close to the bearing under normal operating conditions. This standard applies to industrial machines with fluidbearing films such as turbo compressor, turbine, generator turbine and all electrical equipments that have a rotation between 1,000 RPM to 30,000 RPM with unlimited power [8].

ISO 10816 is the standard for measurements measured on non-rotating components such as pedestals or bearing caps. ISO 10816 is used when measuring using velocity sensor, and for Amurang Power Plant is using ISO 10816-1 (figure. 3.). ISO 10816-1 divided into four classes

Class I: Engine can be separated between driver and driven, or clutched unit consisting of machineries up to $15 \mathrm{~kW}$ (about $20 \mathrm{hp)} \mathrm{(ISO} \mathrm{10816,} \mathrm{2009).}$ 
Class II: Machines (electric motors between $15 \mathrm{~kW}$ (about $20 \mathrm{hp}$ ) to $75 \mathrm{~kW}$ (about $100 \mathrm{hp}$ ) without special foundations, or machining installed on rigid special foundations with power up to $300 \mathrm{~kW}$ (about $400 \mathrm{hp}$ ) [6].

Class III: The machine includes a large prime mover and other large, rotating and mounted engines in relatively rigid foundations of vibration (ISO 10816, 2009).

Class IV: The machine includes a large prime mover and other large rotating and installed engines in relatively soft foundations for measurable vibration directions (such as generator turbines and gas turbines larger than $10 \mathrm{~mW}$ (approximately $13500 \mathrm{hp}$ ) output [6]

Vibration analysis in this research is using velocity sensor with ISO 10816-1 as a reference. Amurang unit 1 Power Plant is classified as Class IV in ISO 10816-1. Figure 2 shows the vibration category limit in ISO 10816-1.

ISO 7919-3 : 2009 Mechanical vibration -- Evaluation of machine $Y$ uibration by measurements on rotating shafts -- Part 3: Coupled

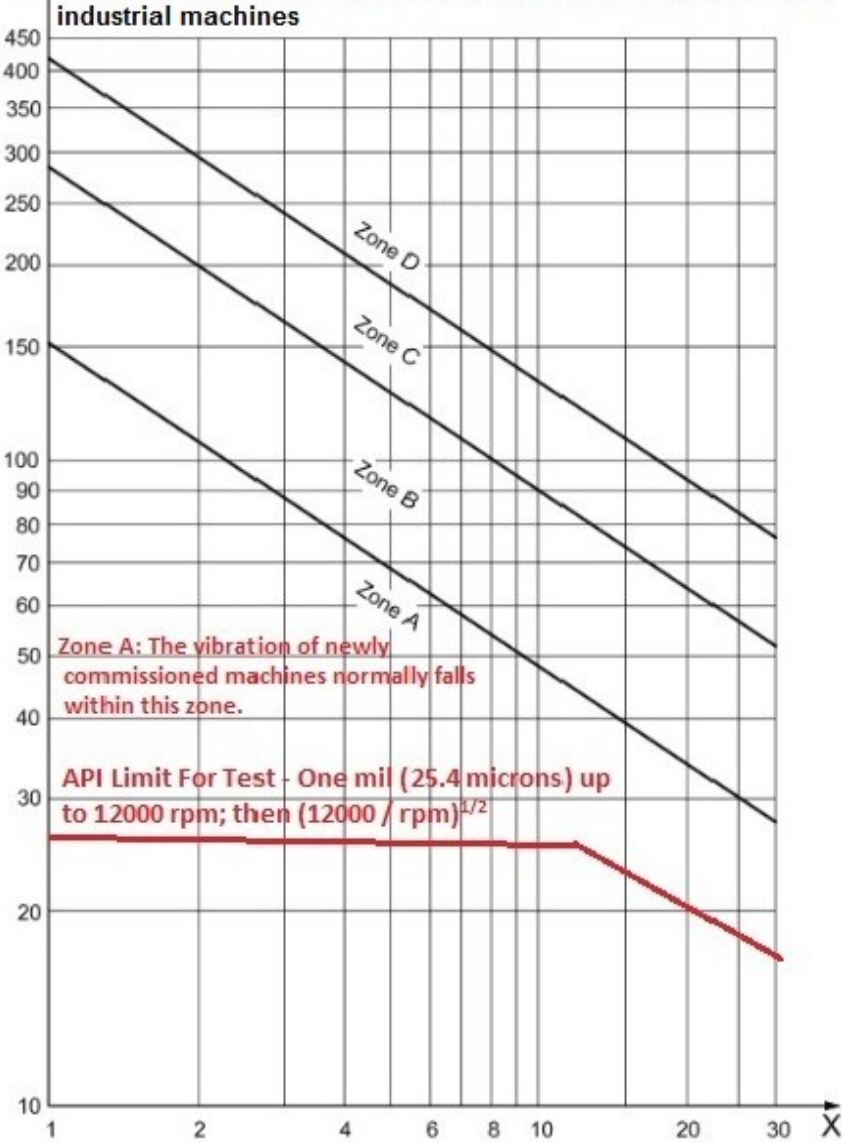

Key

$Y$ peak-to-peak shaft vibration displacement, relative to bearing (um)

$X$ maximum operating speed of the shaft $\times 1000(r / m i n)$

Figure. 2. ISO 7919-3 Vibration Severity Chart

\begin{tabular}{|c|c|c|c|c|c|c|}
\hline \multicolumn{7}{|c|}{ VIBRATION SEVERITY PER ISO 10816-1 } \\
\hline \multicolumn{3}{|c|}{ Machine } & \multirow{2}{*}{$\begin{array}{c}\text { Class I } \\
\text { Small Machines }\end{array}$} & \multirow{2}{*}{$\begin{array}{c}\text { Class II } \\
\text { Medium Machines }\end{array}$} & \multirow{2}{*}{$\begin{array}{c}\text { Class III } \\
\text { Large Rigid Foundation }\end{array}$} & \multirow{2}{*}{$\begin{array}{l}\text { Class IV } \\
\text { Large Soft Foundation }\end{array}$} \\
\hline & in $/ \mathrm{s}$ & $\mathrm{mm} / \mathrm{s}$ & & & & \\
\hline \multirow{12}{*}{ 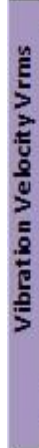 } & 0.01 & 0.28 & & & & \\
\hline & 0.02 & 0.45 & & & & \\
\hline & 0.03 & 0.71 & & \multicolumn{2}{|c|}{ GOOD } & \\
\hline & 0.04 & 1.12 & & & & \\
\hline & 0.07 & 1.80 & & & & \\
\hline & 0.11 & 2.80 & & \multicolumn{2}{|c|}{ SATISFACTORY } & \\
\hline & 0.18 & 4.50 & & & & \\
\hline & 0.28 & 7.10 & & \multicolumn{2}{|c|}{ UNSATISFACTORY } & \\
\hline & 0.44 & 11.20 & & & & \\
\hline & 0.70 & 18.00 & & & & \\
\hline & 1.10 & 28.00 & & \multicolumn{2}{|c|}{ UNAECEPTABIE } & \\
\hline & 1.77 & 45.90 & & & & \\
\hline
\end{tabular}

Figure. 3. ISO 10816-1 Vibration Severity Chart 


\section{RESULTS AND DISCUSSION}

Measurements using displacement probe aims to read the magnitude of vibration displacement in real time in each turbine bearing and steam generator Amurang Unit 1, where the value of vibration displacement on the machine in good condition is 20 microns The displacement probes are also used to measure critical speed during the starting process, in order for operators to immediately avoid such critical speeds.

The largest vibration value in the displacement sensor measurement is the bearing 1 on the displacement probe of $\mathrm{X}$ and $\mathrm{Y}$ positions with vibration values of 77 and 52 microns, bearing 4 on the displacement probe of $\mathrm{X}$ and $\mathrm{Y}$ positions with vibration values of 81 and 67 microns, it is necessary to have vibration analysis using velocity sensor with CSI 2600.

The measurement position of the measurements using displacement probes is shown in Figure 4 and 5. The measurement data using displacement probes is shown in the table. 2. Based on table 2, vibration increases in bearing 1,3 , and 4 . It is necessary to do vibration analysis using velocity sensor with CSI 2600 .

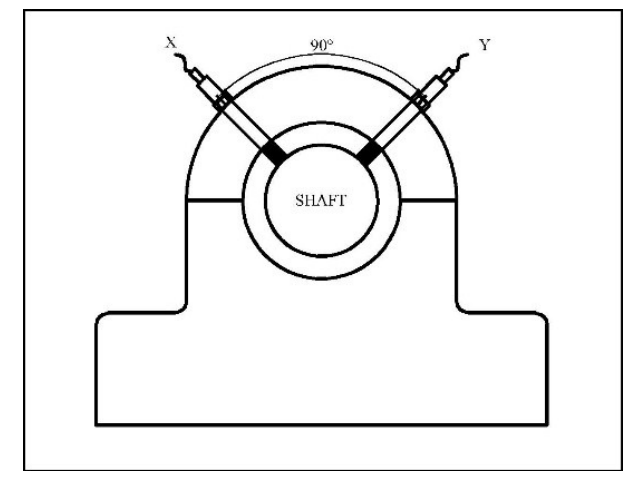

Figure. 4. Displacement probe posision front view

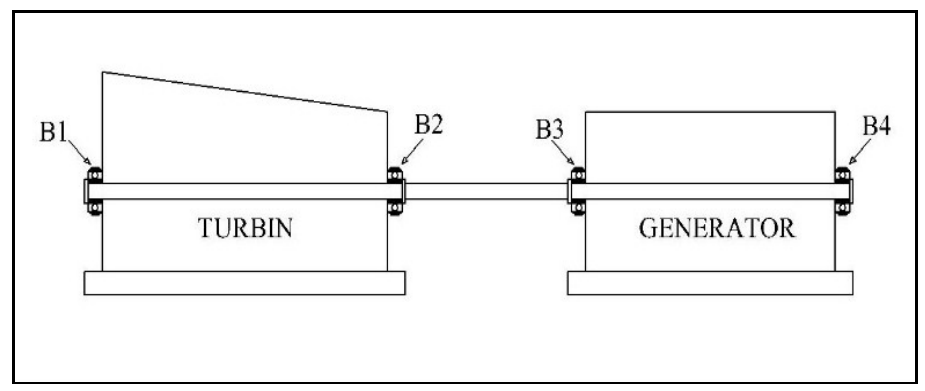

Figure. 5. Displacement probe posision side view

Based on the measurement result using velocity sensor, the results of vibration reading are shown in table 3 . It is shown that the overall vibration value does not reach the maximum operational safe limit of the steam power plant $(7.1 \mathrm{~mm} / \mathrm{s})$ based on the ISO 10816-1 standard. However, in the measurement results, there are some indications of damage on

TABLE. 2.

RESUlTS FROM VELOCITY SENSOR ON BEARING 1-4 AMURANG POWER PlANT

\begin{tabular}{cccc}
\hline Bearing & Dominant Frequencies & Vibration Values on Dominant Frequency & Harmonic Frequencies \\
\hline $1 \mathrm{X}$ & $1 \mathrm{x}$ & 77 microns & $2 \mathrm{x}, 3 \mathrm{x}$ \\
$1 \mathrm{Y}$ & $1 \mathrm{x}$ & 52 microns & $2 \mathrm{x}, 3 \mathrm{x}$ \\
$2 \mathrm{X}$ & $1 \mathrm{x}, 2 \mathrm{x}$ & 20 microns and 11 microns & $3 \mathrm{x}, 4 \mathrm{x}, 5 \mathrm{x}, 6 \mathrm{x}, 7 \mathrm{x}$ and $11 \mathrm{x}$ \\
$2 \mathrm{Y}$ & $1 \mathrm{x}, 2 \mathrm{x}$ & 22 microns and 9 microns & $4 \mathrm{x}, 5 \mathrm{x}$ and $6 \mathrm{x}$ \\
$3 \mathrm{X}$ & $1 \mathrm{x}, 2 \mathrm{x}$ & 29 microns and 7 microns & $3 \mathrm{x}, 4 \mathrm{x}, 5 \mathrm{x}, 6 \mathrm{x}, 7 \mathrm{x}$ and $10 \mathrm{x}$ \\
$3 \mathrm{Y}$ & $1 \mathrm{x}, 2 \mathrm{x}, 3 \mathrm{x}$ & 40 microns, 18 microns and 9 microns & $4 \mathrm{x}, 5 \mathrm{x}, 6 \mathrm{x}, 7 \mathrm{x}$ and $8 \mathrm{x}$ \\
$4 \mathrm{X}$ & $1 \mathrm{x}$ & 81 microns & $2 \mathrm{x}, 3 \mathrm{x}, 4 \mathrm{x}$ and $5 \mathrm{x}$ \\
$4 \mathrm{Y}$ & $1 \mathrm{x}, 2 \mathrm{x}$ & 67 microns and 21 microns & $3 \mathrm{x}, 4 \mathrm{x}, 5 \mathrm{x}, 6 \mathrm{x}, 7 \mathrm{x}$ and $8 \mathrm{x}$ \\
\hline
\end{tabular}

turbine and generator in Amurang power plant, but they are not severe yet, because it is still within safe limits based on ISO 10816-1. 
International Journal of Marine Engineering Innovation and Research, Vol. 2(1), Dec. 2017. 51-58 (pISSN: $2541-57$ 5972, eISSN: 2548-1479)

TABLE. 3.

RESUlTS FROM VELOCITY SENSOR ON BEARING 1-4 AMURANG POWER PLANT

\begin{tabular}{cccc}
\hline Bearing & Dominant Frequencies & Vibration Values on Dominant Frequency & Harmonic Frequencies \\
\hline $1 \mathrm{H}$ & $1 \mathrm{x}$ and $2 \mathrm{x}$ & $1,5 \mathrm{~mm} / \mathrm{s} \& 2,5 \mathrm{~mm} / \mathrm{s}$ & $7 \mathrm{x}$ and $10 \mathrm{x}$ \\
$1 \mathrm{~V}$ & $1 \mathrm{x}$ and $2 \mathrm{x}$ & $1,5 \mathrm{~mm} / \mathrm{s} \& 0,5 \mathrm{~mm} / \mathrm{s}$ & $3 \mathrm{x}$ to $10 \mathrm{x}$ \\
$1 \mathrm{~A}$ & $1 \mathrm{x}$ and $2 \mathrm{x}$ & $1,6 \mathrm{~mm} / \mathrm{s} \& 1,9 \mathrm{~mm} / \mathrm{s}$ & $3 \mathrm{x}$ to $10 \mathrm{x}$ \\
$2 \mathrm{H}$ & $1 \mathrm{x}$ and $2 \mathrm{x}$ & $1,0 \mathrm{~mm} / \mathrm{s} \& 5,0 \mathrm{~mm} / \mathrm{s}$ & $3 \mathrm{x}$ to $10 \mathrm{x}$ \\
$2 \mathrm{~V}$ & $1 \mathrm{x}$ and $2 \mathrm{x}$ & $0,75 \mathrm{~mm} / \mathrm{s} \& 1,2 \mathrm{~mm} / \mathrm{s}$ & $3 \mathrm{x}$ to $4 \mathrm{x}$ \\
$2 \mathrm{~A}$ & $1 \mathrm{x}$ and $2 \mathrm{x}$ & $1,0 \mathrm{~mm} / \mathrm{s} \& 5,0 \mathrm{~mm} / \mathrm{s}$ & $3 \mathrm{x}$ to $6 \mathrm{x}$ \\
$3 \mathrm{H}$ & $1 \mathrm{x}$ and $2 \mathrm{x}$ & $1,1 \mathrm{~mm} / \mathrm{s} \& 6,1 \mathrm{~mm} / \mathrm{s}$ & $3 \mathrm{x}$ to $8 \mathrm{x}$ \\
$3 \mathrm{~V}$ & $2 \mathrm{x}$ & $2,5 \mathrm{~mm} / \mathrm{s}$ & $1 \mathrm{x}, 3 \mathrm{x}, 4 \mathrm{x}, 6 \mathrm{x}$ and $13 \mathrm{x}$ \\
$3 \mathrm{~A}$ & $1 \mathrm{x}$ and $2 \mathrm{x}$ & $0,6 \mathrm{~mm} / \mathrm{s} \& 4,7 \mathrm{~mm} / \mathrm{s}$ & insignificant \\
$4 \mathrm{H}$ & $1 \mathrm{x}$ and $2 \mathrm{x}$ & $3,8 \mathrm{~mm} / \mathrm{s} \& 4,8 \mathrm{~mm} / \mathrm{s}, 4 \mathrm{x}, 5 \mathrm{x}$ and $13 \mathrm{x}$ \\
$4 \mathrm{~V}$ & $1 \mathrm{x}$ and $2 \mathrm{x}$ & $3,1 \mathrm{~mm} / \mathrm{s} \& 2,1 \mathrm{~mm} / \mathrm{s}$ & $3 \mathrm{x}$ and $13 \mathrm{x}$ \\
$4 \mathrm{~A}$ & $1 \mathrm{x}$ and $2 \mathrm{x}$ & $1,0 \mathrm{~mm} / \mathrm{s} \& 5,0 \mathrm{~mm} / \mathrm{s}$ & $3 \mathrm{x}$ \\
\hline
\end{tabular}
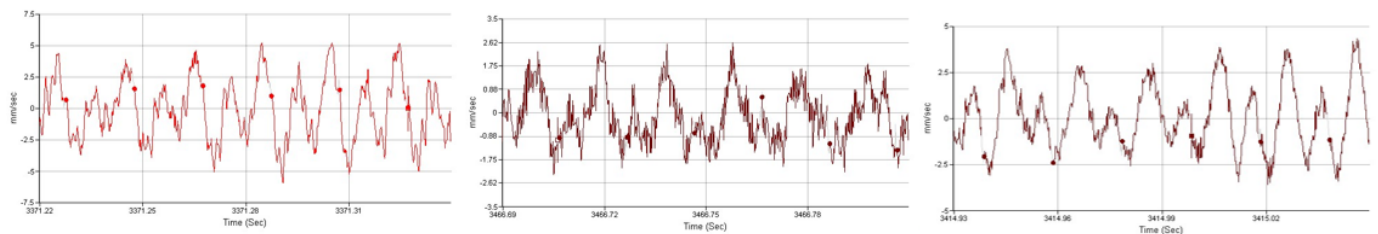

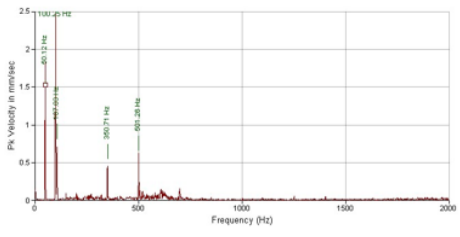

a.

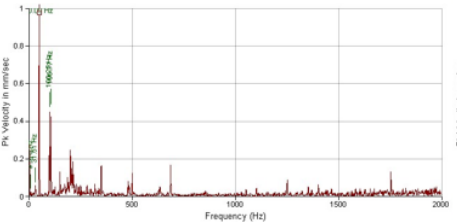

b.

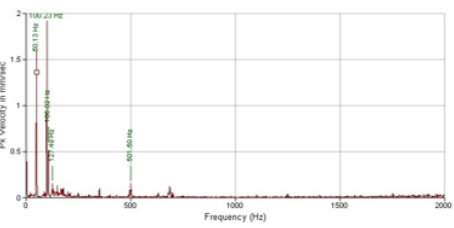

Figure. 6. Waveform and Spectrum vibrations on bearing 1, (a.) is measurements on the horizontal axis, (b.) is measurements on the vertical axis and (c.) is measurements on the axial axis
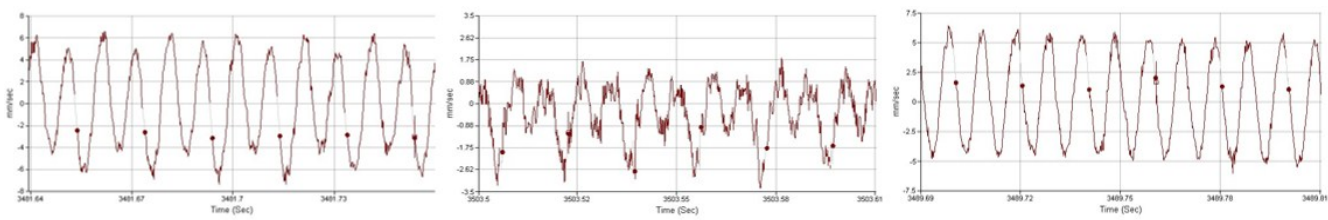

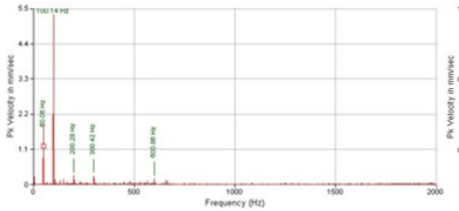

a.

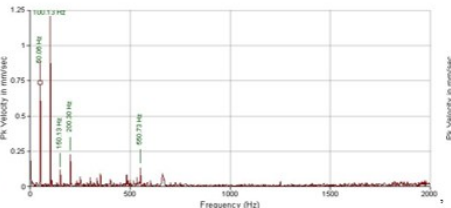

b.

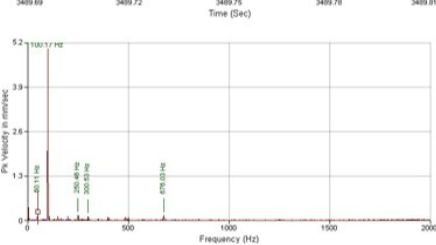

c.

Figure. 7. Waveform and Spectrum vibrations on bearing 2, (a.) is measurements on the horizontal axis, (b.) is measurements on the vertical axis and (c.) is measurements on the axial axis

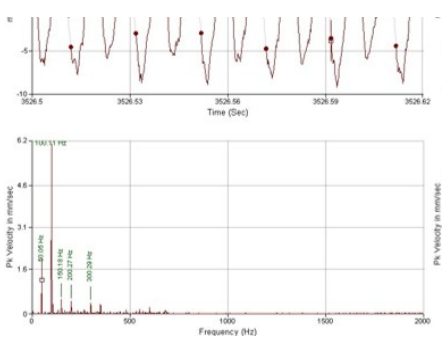

a.

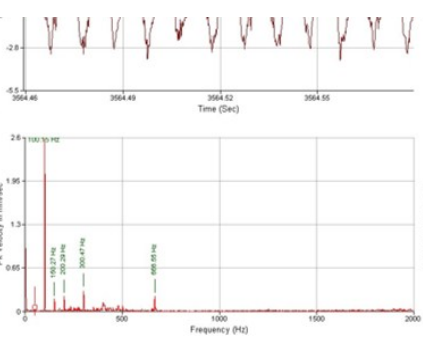

b.
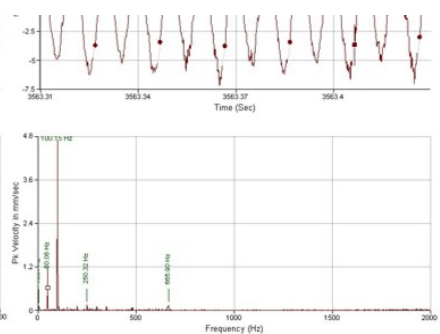

Figure. 8. Waveform and Spectrum vibrations on bearing 3, (a.) is measurements on the horizontal axis, (b.) is measurements on the vertical axis and (c.) is measurements on the axial axis 


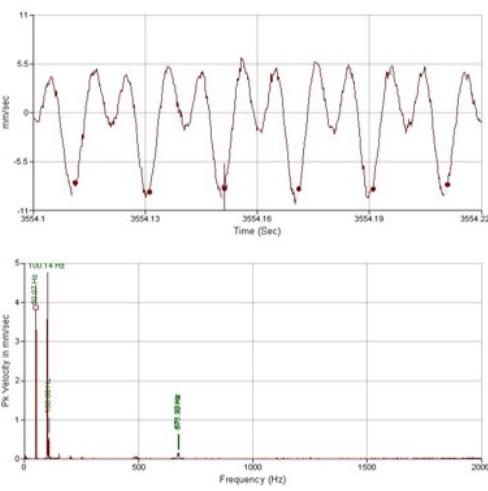

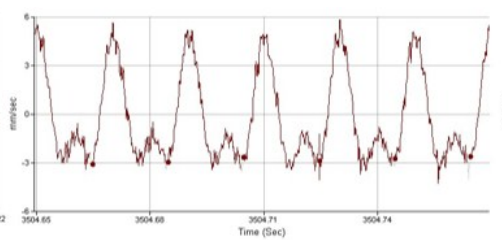

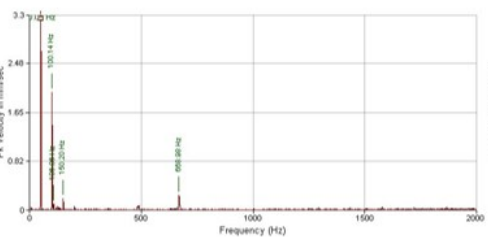

b.
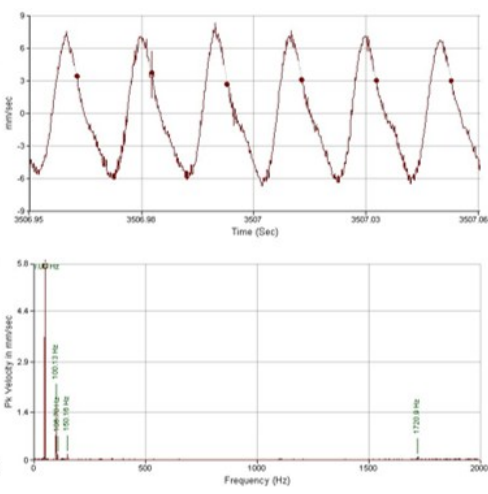

c.

Figure. 9. Waveform and Spectrum vibrations on bearing 4, (a.) is measurements on the horizontal axis, (b.) is measurements on the vertical axis and (c.) is measurements on the axial axis

\section{CONCLUSION}

Based on the analysis that has been done above, through the evidence obtained from the readings of displacement sensors and speed, it can be concluded as follows:

1. Amurang Unit vibration transfer value of Unit 1 Amurang Power Plant has not exceeded the safe limit.

2. Initial indication of abnormalities of Unit 1 Amurang Power Plant is indicated by the increase of vibration value, from 20 microns to the value as shown in table 5.1, but that has not reached the andger limit.

3. The magnitude of the amplitude value in the vibration spectrum indicates the severity of the damage to the Amurang Unit 1 power plant, as described in ISO 7989-3 and ISO 10816-1.

4. Measurement using speed sensor, vibration spectrum indicates the occurrence of journal bearing bearing looseness, as shown in table 5.2 , but the vibration value has not exceeded the andger limit.

\section{REFERENCES}

[1] Port, T., Ashun, J., \& Callaghan, T. J. (2010). Asset Management Excellence (Optimizing Equipment Life-Cycle Decisions, Second Edition). Cleveland: CRC Press.

[2] Bruel \& Kjaer. (1982). Measuring Vibration. Naerum: Brüel \& Kjær (Sound and Vibration Measurement A / S).

[3] Campbell, J. D. (1995). Uptime: Strategies for Excellence in Maintenance Management. New York: Productivity Press.

[4] Kreyszig, E. (2011). Advance Engineering Mathematics. Columbus: John Wiley \& Sons, INC.

[5] Kuemmlee, H., Gross, T., \& Kolerus, J. (2013). Machine Vibrations and Diagnostics The World Of ISO.

[6] ISO 10816. (2009). Mechanical vibration - Evaluation of Machine Vibration by Measurements on Non-Rotating Parts.

[7] ISO 13373. (2002). Condition Monitoring and Diagnostics of Machines.

[8] ISO 7919. (2009). Measurement Made on Rotating Parts.

[9] Betta, G., Liguori, C., Paolillo, A., \& Pietrosanto, A. (2001). A DSP-based FFT-Analyzer for the Fault Diagnosis of Rotating Machine Based on Vibration Analysis. 1.

[10] Mobius Institute. (2017, April 10). Bent Shaft. Taken back from Mobius Institute - Reliability Improvement \& Vibration Analysis Training And Certification: http://www.mobiusinstitute.com/site2/item.asp?LinkID=8024\&iVi be $=1 \&$ sTitle $=$ Bent $\% 20$ shaft

[11] Mobius Institute. (2017, April 10). Cracked or broken tooth. Taken back from Mobius Institute - Reliability Improvement \& Vibration Analysis Training And Certification: http://www.mobiusinstitute.com/site2/item.asp?LinkID=8061\&iVi be $=1 \&$ sTitle $=$ Gearbox

[12] Mobius Institute. (2017, April 10). Journal bearings: Oil whirl. Taken back from Mobius Institute - Reliability Improvement \& Vibration Analysis Training And Certification:
http://www.mobiusinstitute.com/site2/item.asp?LinkID=8029\&iVi be $=1 \&$ sTitle $=$ Journal $\%$ 20bearings

[13] Mobius Institute. (2017, April 10). Journal bearings: Wear / Clearance. Taken back from Mobius Institute - Reliability Improvement \& Vibration Analysis Training And Certification: http://www.mobiusinstitute.com/site2/item.asp?LinkID=8028\&iVi be $=1 \&$ sTitle $=$ Journal $\% 20$ bearings

[14]Mobius Institute. (2017, April 10). Looseness. Taken back from Mobius Institute - Reliability Improvement \& Vibration Analysis Training And Certification: http://www.mobiusinstitute.com/site2/item.asp?LinkID=10004\&iV ibe $=1 \&$ sTitle $=$ Analysis $\% 20$ Definitions

[15] Mobius Institute. (2017, April 10). Misalignment. Retrieved from Mobius Institute - Reliability Improvement \& Vibration Analysis Training And Certification: http://www.mobiusinstitute.com/site2/item.asp?LinkID=10002\&iV ibe $=1 \&$ sTitle $=$ Analysis $\% 20$ Definitions

[16]Mobius Institute. (2017, April 10). Rolling Element Bearing. Taken back from Mobius Institute - Reliability Improvement \& Vibration Analysis Training And Certification: http://www.mobiusinstitute.com/site2/item.asp?LinkID=10003\&iV ibe $=1 \&$ sTitle=Analysis $\% 20$ Definitions

[17] Mobius Institute. (2017, April 10). Unbalance. Taken back from Mobius Institute - Reliability Improvement \& Vibration Analysis Training And Certification: http://www.mobiusinstitute.com/site2/item.asp?LinkID=10001\&iV ibe $=1 \&$ sTitle=Analysis $\% 20$ Definitions

[18] Mobius Institute. (2017, April 10). Vibration Analysis Dictionary. Taken back from Mobius Institute - Reliability Improvement \& Vibration Analysis Training And Certification: http://www.mobiusinstitute.com/site2/item.asp?LinkID=2002

[19] Wowk, V. (1991). Machinery Vibration: Measurement and Analysis. New York: McGraw-Hill.

[20]Moubray, J. (1992). Reliability-Centered Maintenance. New York: Industrial Press Inc.

[21]Rao, S. S. (2004). Mechanical Vibrations. Miami: Pearson Education International.

[22]Priyanta, Dwi, Nurhadi Siswantoro, "Risk Based Inspection of Gas-Cooling Heat Exchanger". International Journal of Marine Engineering and Innovation Research, vol. 1 no. 4, pp. 317-329, September 2017. 